\section{Toxic Effects of Manure, Alfalfa, and Ammonia on Emergence and Growth of Cucumber Seedlings}

\author{
James E. Ells ${ }^{1}$, Ann E. MeSay ${ }^{2}$, and Stephen M. Workman ${ }^{3}$ \\ Department of Horticulture, Colorado State University, Fort Collins, \\ CO 80523
}

\section{Additional index words. cation exchange capacity, Cucumis sativas, Medicago sativa}

\begin{abstract}
Chopped alfalfa (Medicago sativa L.), alfalfa hay extract, and ammonium hydroxide produced free ammonia in media and inhibited both germination and seedling growth of cucumber (Cucumis sativus L.). Toxic levels of ammonia were not produced by the quantities of manure added to the media. Alfalfa extract enhanced cucumber seedling growth in sand medium while inhibiting growth in sand-soil media. This difference is attributed to a reduced level of microbial activity in the sand. With higher levels of microbial activity, rapid decomposition of the extract may have resulted in a burst of ammonia evolution that proved damaging to cucumbers. The natural buffering capacity of the soil medium apparently mitigated the effects of the ammonia. Ammonium hydroxide, which did not depend on microbiological activity to release ammonia, proved lethal to cucumbers grown in sand. A diminished effect on growth was observed as the cation exchange capacity of the medium increased. Because high levels of alfalfa hay and ammonium hydroxide were required to produce toxic levels of ammonia in soil, it is unlikely that cucumbers would be harmed under normal field usage of alfalfa hay.
\end{abstract}

Alfalfa is widely used in crop rotations because it reduces weed populations, penetrates the subsoil, and usually has a positive effect on succeeding crops. However, alfalfa inhibited cucumber germination in laboratory tests (Ells and McSay, 1983, 1991) and prevented the re-establishment of seeded alfalfa in alfalfa fields where dead areas had occurred (Miller, 1983). Alfalfa contains saponins (Megie et al., 1967; Miller, 1983) that inhibit cotton seed germination (Megie et al., 1967). Alfalfa also releases ammonia during decomposition in the soil (Megie et al., 1967), and ammonia can be phytotoxic to cucumbers (Shenk and Wehrmann, 1979; Smith, 1964). Animal manures, which produce ammonia upon decay, also have been associated with inhibition of seed germination (Wong et al., 1983). The concentration of free ammonia in the soil is influenced by soil pH (Cox and Seeley, 1984; Warrent,

Received for publication 26 Jan. 1990. Funding was provided by Colorado Agricultural Experiment Station (Project 156) and Colorado State University Development Fund (Project 5195). The cost of publishing this paper was defrayed in part by the payment of page charges. Under postal regulations, this paper therefore must be hereby marked advertisement solely to indicate this fact.

'Associate Professor.

${ }^{2}$ Researcher I.

${ }^{3}$ Former Research Associate, Dept. of Agronomy.
1962) and soil cation exchange capacity (CEC) (Smith, 1964).

A series of three successive field tests were conducted to determine how cucumber seed planted in soil treated with manure, alfalfa residue, or ammonium hydroxide would perform. Laboratory studies (Ells and McSay, 1983, 1991) demonstrated an inhibition of cucumber germination and growth when alfalfa residue was incorporated into the soil. Therefore, we were interested in determining whether this effect occurred in the field.

A preliminary experiment involved rototilling cattle manure and alfalfa hay into field plots. Neither manure nor alfalfa increased the levels of ammonia in the soil nor caused any inhibition of cucumber growth with rates of manure up to $100 \mathrm{t} \cdot \mathrm{ha}^{-1}$ and alfalfa hay up to $50 \mathrm{t} \cdot \mathrm{ha}^{-1}$ (data not presented). These results indicated that there was little danger of producing inhibitory levels of ammonia in clay loam soils by incorporating common amounts of manure or alfalfa into the soil. However, it remained to be determined whether higher levels of alfalfa or manure would generate inhibitory levels of ammonia and if soil type would affect the results.

We used 1.4-liter pots (130-mm top diameter) that were sunk to the brim into the field to accommodate large quantities of amendments and several sand-soil mixtures. Media were made by mixing air-dried build- er's sand with air-dried soil from the Colorado State Univ. Horticulture Research Center. The soil was a Nunn clay loam (Aridic Argiustoll) with $30 \%$ clay, $7.75 \mathrm{pH}$, and a CEC of $48.81 \mathrm{meq} / 100 \mathrm{~g}$. The CEC test was performed on $100 \mathrm{~g}$ of dried soil by charging all exchange sites with $\mathrm{Na}^{+}$, then removing and measuring the $\mathrm{Na}^{+}$according to Page et al. (1982). Sand-soil mixtures (w/w) of 1:0, $2: 1,1: 2$, and $0: 1$ were prepared and found to have CEC values of 1.68,"8.25, 34.89, and 48.81 , respectively.

These media were amended using the relationship that $0.022 \mathrm{~g} \cdot \mathrm{kg}^{-1}$ of an applied substance (dry-weight basis) is equal to 1 $\mathrm{t} \cdot \mathrm{ha}^{-1}$ on a dry-weight basis. Therefore, 1.1 $\mathrm{g} \cdot \mathrm{kg}^{-1}$ was used to stimulate $50 \mathrm{t} \cdot \mathrm{ha}^{-1}$, and $2.2 \mathrm{~g} \cdot \mathrm{kg}^{-1}$ was used to simulate $100 \mathrm{t} \cdot \mathrm{ha}^{-1}$, on a dry-weight basis. The amendments used were cattle manure $(57.3 \%$ moisture $)$ from a feed lot and chopped alfalfa hay $(<25-\mathrm{mm}$ pieces, $14.7 \%$ moisture). These were added to sand $(0.5 \%$ moisture) and soil $(6.1 \%$ moisture) mixtures to provide media with manure or alfalfa hay at 50 and $100 \mathrm{t} \cdot \mathrm{ha}^{-1}$.

We also used ammonium hydroxide $(28 \%$ $\mathrm{NH}_{3}$ ) and an extract of alfalfa hay. The ammonium hydroxide stock solution was applied at $2.5,5.0$, and $7.5 \mathrm{ml} \cdot \mathrm{kg}^{-1}$ of soil to attain simulated treatments of 50,100, and $200 \mathrm{~kg} \mathrm{~N} / \mathrm{ha}$. The alfalfa extracts for 100 and $300 \mathrm{t}$ alfalfa hay/ha were obtained by soaking $2.2 \mathrm{~g}$ and $6.6 \mathrm{~g}$ of alfalfa hay overnight for every kilogram of medium to be treated. In the morning, the extract was squeezed out of the hay and applied to the media.

The media mixtures were used to fill four 1.4-liter steel containers per treatment. Five 'Triple Mech' cucumber seeds were planted in each container, watered, and taken to the field. A randomized complete block design was used, with each replication being a row of containers. These containers were sunken in soil $15 \mathrm{~cm}$ apart in rows $1 \mathrm{~m}$ apart. A garden sprinkler was then used for irrigation. Soil cores $(25 \times 150 \mathrm{~mm})$ were taken from each pot for ammonia and $\mathrm{pH}$ analysis twice during the experiment. The cores for the four replications were composite and a single analysis was made for each treatment. The tallest seedling in each pot was measured from the soil surface to the growing tip, then the plants were thinned to a single one. Two weeks later, the remaining plant was measured and the experiment was terminated.

The soil samples were extracted with $2 \mathrm{M}$ $\mathrm{KCl}$ according to Page et al. (1982). The total concentration of ammonia solution species $\left(\mathrm{NH}_{4}^{+}+\mathrm{NH} 3\right)$ was determined using flow injection analysis (Lachat, 1986; Ranger, 1988). The concentration of dissolved ammonia $\left(\mathrm{NH}_{3}\right)$ was calculated according to Lindsay (1979). 
Table 1. Cucumber seed germination and seedling growth as influenced by levels of manure, alfalfa hay, $\mathrm{NH}_{4} \mathrm{OH}$, and the $\mathrm{CEC}$ of the growing medium.

\begin{tabular}{|c|c|c|c|c|c|c|c|c|c|}
\hline \multirow{2}{*}{ Treatment } & & \multirow[b]{2}{*}{ Rate/ha } & \multicolumn{3}{|c|}{$\mathrm{NH}_{3}-\mathrm{N}(\mathrm{ppm})^{\mathrm{y}}$} & \multicolumn{2}{|c|}{$\mathrm{pH}$} & \multicolumn{2}{|c|}{$\begin{array}{l}\text { Seedling ht } \\
\text { (mm) }\end{array}$} \\
\hline & & & 3 days $^{x}$ & \multicolumn{2}{|c|}{10 days } & 3 days & 10 days & 10 days & 21 days \\
\hline \multicolumn{10}{|c|}{ Effect due to treatment } \\
\hline \multirow{2}{*}{\multicolumn{2}{|c|}{ Manure (t) }} & 100 & $0.6 b^{w}$ & \multirow{2}{*}{\multicolumn{2}{|c|}{$\begin{array}{l}0.5 \mathrm{c} \\
0.6 \mathrm{c}\end{array}$}} & $8.2 \mathrm{a}$ & $8.3 \mathrm{a}$ & $68 \mathrm{a}$ & $103 \mathrm{a}$ \\
\hline & & 200 & $0.5 \mathrm{~b}$ & & & $8.2 \mathrm{a}$ & $8.3 \mathrm{a}$ & $60 \mathrm{~b}$ & $98 \mathrm{ab}$ \\
\hline \multirow{2}{*}{\multicolumn{2}{|c|}{ Alfalfa $(t)$}} & 50 & $6.3 \mathrm{ab}$ & \multicolumn{2}{|c|}{$\begin{array}{r}7.6 \mathrm{~b} \\
15.5 \mathrm{a}\end{array}$} & $8.1 \mathrm{a}$ & $8.1 \mathrm{a}$ & $5 \mathrm{~d}$ & $8 \mathrm{c}$ \\
\hline & & 100 & $10.3 \mathrm{a}$ & & & $8.0 \mathrm{a}$ & $8.1 \mathrm{a}$ & $3 \mathrm{~d}$ & $8 c$ \\
\hline \multirow{2}{*}{\multicolumn{2}{|c|}{$\mathrm{NH}_{4} \mathrm{OH}(\mathrm{kg} \mathrm{N})$}} & 50 & $1.2 \mathrm{~b}$ & \multicolumn{2}{|c|}{$0.7 \mathrm{bc}$} & $8.1 \mathrm{a}$ & $8.1 \mathrm{a}$ & $60 \mathrm{~b}$ & $98 \mathrm{ab}$ \\
\hline & & 100 & $1.7 \mathrm{~b}$ & \multicolumn{2}{|c|}{$0.5 \mathrm{c}$} & $8.1 \mathrm{a}$ & $8.1 \mathrm{a}$ & $53 \mathrm{c}$ & $93 \mathrm{ab}$ \\
\hline & & 200 & $3.6 \mathrm{~b}$ & \multirow{2}{*}{\multicolumn{2}{|c|}{$\begin{array}{l}1.0 \mathrm{bc} \\
0.3 \mathrm{c}\end{array}$}} & $8.2 \mathrm{a}$ & $8.2 \mathrm{a}$ & $50 \mathrm{c}$ & $90 \mathrm{~b}$ \\
\hline \multicolumn{2}{|l|}{ Control } & & $0.5 \mathrm{~b}$ & & & $8.0 \mathrm{a}$ & $8.0 \mathrm{a}$ & $55 \mathrm{c}$ & $90 \mathrm{~b}$ \\
\hline \multicolumn{10}{|c|}{ Effect due to medium } \\
\hline \multicolumn{2}{|c|}{ Sand : soil medium (ratio) } & $\mathrm{CEC}^{\vee}$ & & & & & & & \\
\hline $1: 0$ & & 1.7 & $1.0 \mathrm{a}^{\mathrm{u}}$ & \multicolumn{2}{|c|}{$1.9 \mathrm{a}$} & $8.5 \mathrm{a}$ & $8.5 \mathrm{a}$ & $33 \mathrm{~b}$ & $53 \mathrm{c}$ \\
\hline $2: 1$ & & 8.3 & $4.3 \mathrm{a}$ & \multirow{2}{*}{\multicolumn{2}{|c|}{$\begin{array}{l}5.0 \mathrm{a} \\
3.3 \mathrm{a}\end{array}$}} & $8.2 \mathrm{~b}$ & $8.3 \mathrm{a}$ & $48 \mathrm{a}$ & $70 \mathrm{~b}$ \\
\hline $1: 2$ & & 34.9 & $3.6 \mathrm{a}$ & & & $7.9 c$ & $8.0 \mathrm{~b}$ & $50 \mathrm{a}$ & $83 \mathrm{a}$ \\
\hline $0: 1$ & & 48.8 & $3.4 \mathrm{a}$ & \multicolumn{2}{|c|}{$3.0 \mathrm{a}$} & $7.8 \mathrm{c}$ & $7.8 \mathrm{~b}$ & $48 \mathrm{a}$ & $85 \mathrm{a}$ \\
\hline \multicolumn{6}{|c|}{ Treatment $\times$ media interaction } & & & $* *$ & $* *$ \\
\hline \multicolumn{10}{|c|}{$\begin{array}{l}\text { ×Days after planting. } \\
\text { "DData are means of four media and four replications. } \\
\text { } \mathrm{C} C \mathrm{C}=\mathrm{cation} \text { exchange capacity, meq } / 100 \mathrm{~g} \text {. } \\
\text { "Data are means of cight treatments and four replications. } \\
{ }^{* *} \text { Significant at } P=0.01 \text {. }\end{array}$} \\
\hline \multirow{3}{*}{$\begin{array}{l}\text { Sand : soil } \\
\text { ratio }\end{array}$} & & & & & ng ht & $\mathrm{m})^{2}$ & & & \\
\hline & & & & & & & $\begin{array}{c}\mathrm{NH}_{4} \mathrm{OH} \\
(\mathrm{kg} \mathrm{N} / \mathrm{ha})\end{array}$ & & \\
\hline & $\mathrm{CEC}^{\mathrm{y}}$ & 100 & 200 & 50 & 100 & 50 & 100 & 200 & Control \\
\hline & & & & Days & plantir & & & & \\
\hline 1:0 & 1.7 & $58 \mathrm{~b}$ & $52 \mathrm{~b}$ & $13 \mathrm{a}$ & $13 \mathrm{a}$ & $40 \mathrm{c}$ & $25 \mathrm{~b}$ & $25 \mathrm{~b}$ & $38 \mathrm{~b}$ \\
\hline $2: 1$ & 8.3 & $77 \mathrm{a}$ & $63 \mathrm{ab}$ & $3 a$ & $0 \mathrm{a}$ & $58 \mathrm{~b}$ & $58 \mathrm{a}$ & $58 \mathrm{c}$ & $59 \mathrm{a}$ \\
\hline $1: 2$ & 34.9 & $73 a b$ & $69 \mathrm{a}$ & $0 \mathrm{a}$ & $0 \mathrm{a}$ & $70 \mathrm{a}$ & $63 \mathrm{a}$ & $56 \mathrm{a}$ & $61 \mathrm{a}$ \\
\hline $0: 1$ & 48.8 & $59 \mathrm{~b}$ & $58 \mathrm{ab}$ & $0 \mathrm{a}$ & $0 \mathrm{a}$ & 69 a & $67 \mathrm{a}$ & 55 a & 59 a \\
\hline & & & & Days & plantin & & & & \\
\hline $1: 0$ & 1.7 & $78 \mathrm{~b}$ & $83 \mathrm{~b}$ & $28 \mathrm{a}$ & $25 \mathrm{a}$ & $59 \mathrm{c}$ & $41 \mathrm{~b}$ & $56 \mathrm{c}$ & $58 \mathrm{c}$ \\
\hline $2: 1$ & 8.3 & $102 \mathrm{a}$ & $97 \mathrm{ab}$ & $\mathrm{Ob}$ & $0 \mathrm{a}$ & $95 \mathrm{~b}$ & $94 \mathrm{a}$ & $86 \mathrm{~b}$ & $91 \mathrm{~b}$ \\
\hline $1: 2$ & 34.9 & $116 \mathrm{a}$ & $111 \mathrm{a}$ & $\mathrm{Ob}$ & $0 \mathrm{a}$ & $111 \mathrm{ab}$ & $116 \mathrm{a}$ & $105 \mathrm{a}$ & 106 a \\
\hline $0: 1$ & 48.8 & 109 a & $97 \mathrm{ab}$ & $0 \mathrm{~b}$ & $0 \mathrm{a}$ & $122 \mathrm{a}$ & $114 \mathrm{a}$ & $109 \mathrm{a}$ & $100 \mathrm{ab}$ \\
\hline
\end{tabular}

${ }^{2}$ Mean separation in columns at $P=0.05$.

${ }^{y} \mathrm{CEC}=$ cation exchange capacity, meq/100 g.

Response to low levels of soil ammonia (Expt. 1). A factorial design used four sandsoil media, eight ammonia treatments, and four replications. The treatments consisted of manure at 100 and $200 \mathrm{t} \cdot \mathrm{ha}^{-1}$; chopped alfalfa at 50 and $100 \mathrm{t} \cdot \mathrm{ha}^{-1}$; ammonia hydroxide at 50, 100, and $200 \mathrm{~kg} \mathrm{~N} / \mathrm{ha}$; and a control for each medium.

Relative to the control, manure at 100 $\mathrm{t} \cdot \mathrm{ha}^{-1}$ increased plant height. Alfalfa at 50 and $100 \mathrm{t} \cdot \mathrm{ha}^{-1}$ greatly reduced plant height. Alfalfa at $100 \mathrm{t} \cdot \mathrm{ha}^{-1}$ elevated the level of ammonia in the soil both 3 and 10 days after planting. This rise was associated with a reduction in seedling height at both 10 and 21 days after planting. Ammonium hydroxide treatments had no effect on ammonia level, $\mathrm{pH}$, or seedling height (Table 1).

A pH increase was detected in the sand medium (1:0) 3 and 10 days after planting.
This increase was associated with a reduction in seedling height after 10 and 21 days (Table 1). The low CEC may have permitted the $\mathrm{pH}$ to increase in the sand, while the greater CEC of the soil may have kept the $\mathrm{pH}$ relatively stable (Smith, 1964).

The treatment $\times$ media interaction was highly significant for cucumber seedling height at 10 and 21 days after planting (Table 2 ). After 10 days, sand generally proved to be the poorest medium for growing cucumbers. Cucumber seedlings in control and all the ammonium treatments performed worse in sand (1:0) than in the other media. After 21 days, sand was still the poorest medium for the ammonium treatment and the control, but the best treatment for alfalfa at $50 \mathrm{t} \cdot \mathrm{ha}^{-1}$ (Table 2). Since sand also had the lowest CEC and the highest $\mathrm{pH}$ after 3 days (Table 1), we hypothesize that ammonia, CEC, and
$\mathrm{pH}$ combined to produce this poor performance in the following fashion: The concentration of ammonia in the soil depends on $\mathrm{pH}$, since ammonia cannot exist at $\mathrm{pH} 7$ or below. However, as the soil $\mathrm{pH}$ increases (as it did in the sand), the reaction $\mathrm{NH}_{3}+\mathrm{H}^{+}$ $\Rightarrow \mathrm{NH}_{4}^{+}$shifts to the left, producing free ammonia in the soil. Ammonia above $10 \mathrm{ppm}$ is phytotoxic to cotton (Megie et al., 1967). Cucumber seeds germinated in the sand medium amended with alfalfa. Germination was almost totally inhibited in a soil medium containing alfalfa. Since ammonia production from alfalfa hay depends on microbial activity, we suspect that sand had lower levels of biological activity and, therefore, did not generate the high levels of ammonia that would have inhibited cucumber germination.

Response to high levels of soil ammonia (Expt. 2). The factorial design for this ex- 
Table 3. Cucumber seed germination and seedling growth as influenced by levels of alfalfa hay extract (aIf. ext.), $\mathrm{NH}_{4} \mathrm{OH}$, and the $\mathrm{CEC}$ of the growing medium. ${ }^{2}$

\begin{tabular}{|c|c|c|c|c|c|c|c|}
\hline \multirow[b]{2}{*}{ Treatment } & \multirow[b]{2}{*}{ Rate/ha } & \multicolumn{2}{|c|}{$\mathrm{NH}_{3}-\mathrm{N}(\mathrm{ppm})^{\mathrm{y}}$} & \multicolumn{2}{|c|}{$\mathrm{pH}$} & \multicolumn{2}{|c|}{ Seedling ht (mm) } \\
\hline & & 4 days ${ }^{x}$ & 11 days & 4 days & 11 days & 7 days & 18 days \\
\hline \multicolumn{8}{|c|}{ Effect due to treatment } \\
\hline Alfalfa extract (t) & 100 & $2.1 \mathrm{~b}^{\mathrm{w}}$ & $0.6 \mathrm{~b}$ & $8.2 \mathrm{a}$ & $8.2 \mathrm{~b}$ & 35 a & $49 \mathrm{a}$ \\
\hline & 300 & $3.3 \mathrm{~b}$ & $5.5 \mathrm{~b}$ & $8.2 \mathrm{a}$ & $8.4 \mathrm{a}$ & $15 \mathrm{c}$ & $32 \mathrm{~b}$ \\
\hline $\mathrm{NH}_{4} \mathrm{OH}(\mathrm{kg} \mathrm{N})$ & 200 & $2.6 \mathrm{~b}$ & $0.5 \mathrm{~b}$ & $8.0 \mathrm{a}$ & $8.1 \mathrm{~b}$ & $30 \mathrm{a}$ & $51 \mathrm{a}$ \\
\hline & 1000 & $19.4 \mathrm{~b}$ & $5.2 \mathrm{~b}$ & $8.2 \mathrm{a}$ & $8.1 \mathrm{~b}$ & $10 \mathrm{~cd}$ & $22 \mathrm{c}$ \\
\hline & 2000 & $42.9 \mathrm{a}$ & $26.8 \mathrm{a}$ & $8.6 \mathrm{a}$ & $8.3 \mathrm{~b}$ & $5 \mathrm{~d}$ & $8 \mathrm{~d}$ \\
\hline Control & & $0.9 \mathrm{~b}$ & $0.4 b$ & 7.9 a & $8.1 \mathrm{~b}$ & $23 \mathrm{~b}$ & $47 a$ \\
\hline \multicolumn{8}{|c|}{ Effect due to medium } \\
\hline Sand : soil medium (ratio) & $\mathrm{CEC}^{v}$ & & & & &. & \\
\hline $1: 0$ & 1.7 & $3.8 \mathrm{a}^{\mathrm{u}}$ & $1.6 \mathrm{a}$ & 8.4 a & $8.6 \mathrm{a}$ & $20 \mathrm{~b}$ & $43 \mathrm{a}$ \\
\hline $2: 1$ & 8.3 & $15.0 \mathrm{a}$ & $11.5 \mathrm{a}$ & $8.3 \mathrm{a}$ & $8.3 \mathrm{~b}$ & $15 \mathrm{~b}$ & $25 \mathrm{~b}$ \\
\hline $1: 2$ & 34.9 & $16.4 \mathrm{a}$ & $8.9 \mathrm{a}$ & $8.0 \mathrm{a}$ & $8.0 \mathrm{c}$ & $15 \mathrm{~b}$ & $29 \mathrm{~b}$ \\
\hline $0: 1$ & 48.8 & $12.2 \mathrm{a}$ & $3.9 \mathrm{a}$ & $7.9 \mathrm{a}$ & $7.8 \mathrm{~d}$ & $25 \mathrm{a}$ & $42 \mathrm{a}$ \\
\hline Treatment $\times$ media interact & & & & & & . & ** \\
\hline
\end{tabular}

${ }^{2}$ Values in a column followed by different letters are different at $P=0.05$.

'Calculated $\mathrm{NH}_{3}-\mathrm{N}$ based on $\mathrm{NH}_{3}+\mathrm{H}^{+}=\mathrm{NH}_{4}^{+} \frac{\log \mathrm{K}^{\circ}}{9.28}$.

${ }^{\times}$Days after planting.

"Each value is the mean of four media and four replications.

${ }^{\circ} \mathrm{CEC}=$ cation exchange capacity, meq/100 g.

"Each value is the mean of eight treatments and four replications.

${ }^{*, * *}$ Significant at $P=0.05$ and 0.01 , respectively.

Table 4. Cucumber seedling height $(\mathrm{mm})$ as influenced by media and treatment of Table $3 .{ }^{z}$

\begin{tabular}{|c|c|c|c|c|c|c|c|}
\hline \multirow{2}{*}{$\begin{array}{l}\text { Sand : soil } \\
\text { medium }\end{array}$} & \multirow[b]{2}{*}{ CEC } & \multicolumn{2}{|c|}{$\begin{array}{c}\text { Alfalfa extract } \\
\left(t \cdot h a^{-1}\right)\end{array}$} & \multicolumn{3}{|c|}{$\begin{array}{c}\mathrm{NH}_{4} \mathrm{OH} \\
(\mathrm{kg} \mathrm{N} / \mathrm{ha}) \\
\end{array}$} & \multirow[b]{2}{*}{ Control } \\
\hline & & 100 & 300 & 200 & 1000 & 2000 & \\
\hline \multicolumn{8}{|c|}{7 Days after planting } \\
\hline $1: 0$ & 1.7 & $34 \mathrm{a}$ & $39 \mathrm{a}$ & $22 \mathrm{~b}$ & $0 \mathrm{~b}$ & $0 \mathrm{a}$ & $19 \mathrm{~b}$ \\
\hline $2: 1$ & 8.3 & $33 \mathrm{a}$ & $0 \mathrm{c}$ & $38 \mathrm{a}$ & $0 \mathrm{~b}$ & $0 \mathrm{a}$ & $20 \mathrm{~b}$ \\
\hline $1: 2$ & 34.9 & $34 \mathrm{a}$ & $0 \mathrm{c}$ & $22 \mathrm{~b}$ & $11 \mathrm{ab}$ & $0 \mathrm{a}$ & $19 \mathrm{~b}$ \\
\hline $0: 1$ & 48.8 & $36 a$ & $16 \mathrm{~b}$ & 34 a & 21 a & 14 a & $31 a$ \\
\hline \multicolumn{8}{|c|}{18 Days after planting } \\
\hline $1: 0$ & 1.7 & $80 \mathrm{a}$ & $80 \mathrm{a}$ & $58 \mathrm{a}$ & $0 \mathrm{~b}$ & $0 \mathrm{~b}$ & $40 \mathrm{~b}$ \\
\hline $2: 1$ & 8.3 & $41 \mathrm{~b}$ & $10 \mathrm{c}$ & $47 \mathrm{bc}$ & $8 \mathrm{~b}$ & $0 \mathrm{~b}$ & $46 \mathrm{ab}$ \\
\hline $1: 2$ & 34.9 & $44 \mathrm{~b}$ & $4 c$ & $44 c$ & $38 \mathrm{a}$ & $0 \mathrm{~b}$ & $45 \mathrm{ab}$ \\
\hline $0: 1$ & 48.8 & $29 \mathrm{~b}$ & $35 \mathrm{~b}$ & $55 a b$ & $40 \mathrm{a}$ & $33 a$ & $57 \mathrm{a}$ \\
\hline
\end{tabular}

${ }^{2}$ Values in columns followed by different letters are different at $P=0.05$; each value is the mean of four replications.

periment employed four sand-soil media, six ammonia treatments, and four replications. Alfalfa extract treatments were used instead of chopped alfalfa hay, since the efficacy of chopped alfalfa had already been demonstrated (Expt. 1). Manure, as in Expt. 1, was not used because little ammonia was produced. Ammonium hydroxide concentrations were increased to 200,1000, and 2000 $\mathrm{kg} \mathrm{N} / \mathrm{ha}$ to determine the threshold of ammonia inhibition.

The alfalfa extract at $100 \mathrm{t} \cdot \mathrm{ha}^{-1}$ had increased seedling height after 7 days, whereas the 300-t rate had reduced seedling height at 7 and 18 days, relative to the control. Ammonium hydroxide at $200 \mathrm{~kg} \mathrm{~N} / \mathrm{ha}$ had increased seedling height after 7 days, but 1000 $\mathrm{kg} \mathrm{N}$ had reduced it at 7 and 18 days, and $2000 \mathrm{~kg} \mathrm{~N}$ had increased ammonia in the medium after 4 and 11 days and reduced seedling height at 7 and 18 days (Table 3 ).

The sand medium had a high $\mathrm{pH}$ after 11 days, and the soil medium had the tallest seedlings after 7 days. The interaction be- seedlings responded with increased growth. However, when decay is so rapid that a burst of ammonia is released, the alfalfa extract could then become toxic to cucumbers if the medium did not have a CEC great enough to keep the $\mathrm{pH}$ from temporarily rising. This appeared to have been the case with the soil medium (0: 1$)$, where total inhibition was averted but seedling height was reduced. Ammonium hydroxide, which does not depend on decay for ammonia release, was most devastating on cucumber seedlings grown in sand where there was little buffering capacity to keep the $\mathrm{pH}$ from rising (Table 4).

The fact that seedlings belatedly appeared after 18 days in sand-soil media treated with either alfalfa extract or ammonium hydroxide indicates that ammonia can inhibit germination without killing the seed and that germination can occur when ammonia has dissipated (Table 4).

We hypothesize that inhibition was due to ammonia in both the alfalfa and $\mathrm{NH}_{4} \mathrm{OH}$ treatments and that the difference in reaction was due to the low level of microbial activity in the sand medium.

We, therefore, have concluded that ammonia can be generated by incorporating alfalfa into soil and that, in excess, ammonia is toxic to cucumbers. However, it appears that neither manure, alfalfa, nor anhydrous ammonia, used at the proper rates, pose any danger to a crop of field cucumbers.

\section{Literature Cited}

Cox, D.A. and J.G. Seeley. 1984. Ammonium injury and poinsettia: Effects of $\mathrm{NH}_{4}-\mathrm{N}$ : $\mathrm{NO}_{3}-\mathrm{N}$ ratio and $\mathrm{pH}$ control in solution culture on growth, $\mathrm{N}$ absorption and $\mathrm{N}$ utilization. $\mathrm{J}$. Amer. Soc. Hort. Sci. 109:57-62.

Ells, J.E. and A.E. McSay. 1983. Allelopathic effect of plant residues on cucumber germination and seedling growth. Colorado State Univ. Agr. Expt. Sta. Progress Rpt. 7.

Ells, J.E. and A.E. McSay. 1991. Allelopathic effects of alfalfa plant residues on emergence and growth of cucumber seedlings. 26:368-370.

Lachat Instruments. 1986. Method No. 10-10706-1A. Determination of ammonia in water and wastewater. Method approved by USEPA. Lachat Instruments, Mequon, Wis.

Lindsay, W.L. 1979. Chemical equilibria in soils. Wiley, New York.

Megie, C.A., R.W. Pearson, and A.E. Mitbold. 1967. Toxicity of decomposing crop residues to cotton germination and seedling growth. Agron. J. 59:197-199.

Miller, D.A. 1983. Allelopathic effects of alfalfa. J. Chem. Ecol. 9(8):1059-1072.

Page, A.L., R.H. Miller, and D.R. Kenney. 1982. Methods of soil analysis. Part 2. Chemical and microbiological properties. Agron. Monogr. 9:648-649.

Ranger, C.B. 1988. USEPA regulation of FIA method for NPDES and NIPDWR monitoring of water and wastes. Amer. Lab. 20(9):42-49.

Shenk, M. and J. Wehrmann. 1979. Influence of ammonia in nutrient solution on growth and metabolism of cucumber plants. Plant \& Soil 52:403-414.

Smith, J.H. 1964. Relationships between soil cation-exchange capacity and the toxicity of am- 
monia to the vitrification process. Soil. Sci. Soc. Amer. Proc. 28:640-644.

Warrent, K.S. 1962. Ammonia toxicity and pH.
Nature (London) 195:47-49.

Wong, M.H., Y.H. Cheung, and C.L. Cheung.

1983. The effects of ammonia and ethylene ox- ide in animal manure and sewage sludge on seed germination and root elongation of Brassica para chinensis. Env, Pollut. Ser. A 30:109-123. 